\title{
Protein requirements of growing indigenous chickens during the 14-21 weeks growing period
}

\author{
A.M. Kingori, J.K.Tuitoek ${ }^{\#}$, H.K. Muiruri and A.M. Wachira ${ }^{1}$ \\ Egerton University, P.O. Box 536, Njoro, Kenya \\ ${ }^{1}$ National Animal Husbandry Research Centre, P.O. Box 25, Naivasha, Kenya
}

\begin{abstract}
A study was conducted to investigate the growth response of growing indigenous chickens between 14 and 21 weeks of age to diet protein level. The chickens were offered diets ad libitum with 100, 120, 140, 160 and $180 \mathrm{~g}$ crude protein (CP)/kg diet. Body weight and feed intake of the birds were recorded weekly. Feed intake and weight gain increased significantly between the 100 and $160 \mathrm{~g} \mathrm{CP} / \mathrm{kg}$ diets where-after they plateau. Feed efficiency measured by feed conversion ratio improved with increasing dietary protein level up to $160 \mathrm{~g} \mathrm{CP} / \mathrm{kg}$ after which there was no further improvement. It is concluded that the $\mathrm{CP}$ requirements for these chickens between 14 and 21 weeks of age is $160 \mathrm{~g} / \mathrm{kg}$.
\end{abstract}

Keywords: Indigenous chickens, protein requirements, 14-21 weeks

"Corresponding author. E-mail: jk_tuitoek@yahoo.com

\section{Introduction.}

Indigenous chickens are widely distributed in the rural areas of tropical countries where they are kept by a majority of the rural poor and contribute more than $50 \%$ of the total eggs and meat consumed (Mukherjee, 1992). These birds are reared under extensive management systems characterized by low capital input and consequently low economic risks (Gichohi \& Maina, 1992). Producers are usually smallholders, landless individuals and industrial labourers who rear these birds because of their adaptability and compatibility to the environment and activities of the owners. These chickens are hardy, adapt well to rural environments, survive on little inputs and adjust to fluctuations in feed availability.

Human diets in the rural communities are deficient in protein both qualitatively and quantitatively (FAO, 1997). Furthermore, rural income levels are low. Improving poultry productivity will improve protein nutrition and will diversify and increase income levels of the rural population. In addition, consumers prefer meat from indigenous chickens because of its characteristic leanness and pigmentation. In developing countries there is tremendous potential for increasing productivity of indigenous chickens. The productivity of indigenous chickens can be improved by providing appropriate housing, disease control and good nutrition (Ndegwa et al., 1996).

The nutritional requirements of commercial chickens, turkeys, pheasants and related poultry stock have been estimated (Blum et al., 1975; Woodard et al., 1977; Potter \& Shelton, 1979; Yamane et al., 1980; NRC, 1984). Information on the protein and energy requirements of indigenous chickens is, however, limited. Chemjor (1998) reported that a dietary protein level of $130 \mathrm{~g} / \mathrm{kg}$ during the 14-21 weeks growth phase was adequate for indigenous chickens. In the current study the crude protein (CP) requirements of growing indigenous chickens in confinement from the $14^{\text {th }}$ to $21^{\text {st }}$ weeks of age were estimated. Knowledge of the protein requirements of these chickens will allow producers to strategically offer supplementary sources to meet protein deficits. The additional supplements should increase productivity of these chickens under scavenging conditions.

\section{Materials and Methods}

Fertile eggs from a composite of indigenous chickens were used to produce 150 chicks for this experiment. The chicks were vaccinated against common diseases (Marek's, Newcastle, Gumboro, fowl-pox and typhoid) and were offered commercial type diets until their $13^{\text {th }}$ week of age $(180 \mathrm{~g} \mathrm{CP} / \mathrm{kg}$ up to 8 weeks and $160 \mathrm{~g} \mathrm{CP} / \mathrm{kg}$ up to 13 weeks of age). During the $14^{\text {th }}$ to the $21^{\text {st }}$ week of age, the chickens were offered the experimental diets. Five experimental diets (Table 1) were formulated to contain CP concentrations of $100,120,140,160$ and $180 \mathrm{~g} / \mathrm{kg}$ (treatments 1 to 5 respectively). Feed intake, weight gain and feed efficiency were measured on all replications. After allowing for an adaptation period of seven days (week 
13), feed consumption and the weights of the birds were recorded on a weekly basis. Water and feed were provided ad libitum.

Table 1 Composition of the experimental diets

\begin{tabular}{|c|c|c|c|c|c|}
\hline & Diet 1 & Diet 2 & Diet 3 & Diet 4 & Diet 5 \\
\hline \multicolumn{6}{|l|}{ Ingredient (g/kg) } \\
\hline Maize & 929.2 & 888.8 & 848.0 & 809.3 & 766.0 \\
\hline $\begin{array}{l}\text { Maize gluten meal (prairie), } \\
60 \%\end{array}$ & 24.9 & 48.4 & 71.6 & 95.5 & 119.0 \\
\hline Fish meal & 20.9 & 40.7 & 60.3 & 80.2 & 100.0 \\
\hline Limestone & 10.0 & 10.0 & 10.0 & 10.0 & 10.0 \\
\hline Dicalcium phosphate & 10.0 & 7.0 & 5.0 & 0 & 0 \\
\hline Iodized salt $(\mathrm{NaCl})$ & 2.5 & 2.5 & 2.5 & 2.5 & 2.5 \\
\hline Premix ${ }^{*}$ & 2.5 & 2.5 & 2.5 & 2.5 & 2.5 \\
\hline \multicolumn{6}{|l|}{ Calculated analysis $(\mathrm{g} / \mathrm{kg})$} \\
\hline Crude protein & 100 & 120 & 140 & 160 & 180 \\
\hline Calcium & 6.7 & 6.9 & 7.2 & 7.0 & 7.7 \\
\hline Total phosphorus & 5.0 & 5.0 & 5.1 & 4.6 & 5.1 \\
\hline
\end{tabular}

*Each gram contains:

Vitamins: A - 4500 I.U.; $D_{3}-900$ I.U.; E - 81 U.; $\mathrm{K}_{3}-1 \mathrm{mg}$; $\mathrm{B}_{1}-0.7 \mathrm{mg}$; $\mathrm{B}_{2}-1.75 \mathrm{mg}$; $\mathrm{B}_{6}-1.5 \mathrm{mg}$; $\mathrm{B}_{12}-0.0048 \mathrm{mg}$; - $40.0 \mathrm{mg}$; nicotinic acid - $17.5 \mathrm{mg}$; pantothenic acid - $4.0 \mathrm{mg}$; biotin - $0.02 \mathrm{mg}$; folic acid - $0.4 \mathrm{mg}$; choline chloride $140 \mathrm{mg}$; carophyll $(\mathrm{R}+\mathrm{Y})-13 \mathrm{mg}$.

Minerals: Mn - 48 mg; Fe - 12.8 mg; Zn - 14.4 mg; Cu - 1.6 mg; Co - 0.064 mg; I - 0.448 mg; Se - 0.04 mg.

A total of 25 deep litter pens, each measuring $1 \mathrm{~m} \mathrm{x} 3 \mathrm{~m}$, was used in the experiment. Birds were randomly allocated within sex to the pens so that there were six birds ( 3 males and 3 females) per pen. The pen floors were covered with six $\mathrm{cm}$ of wood shavings as litter material. These experimental pens were constructed within a house in which a $1 \mathrm{~m}$ high stone wall was covered with wire mesh. The mesh wire allowed for ventilation and natural light. The diets were then randomly allocated to the pens. Five replications were provided for each dietary treatment.

All data were subjected to analysis of variance for a completely randomised design using Genstat 5 (1995) and each pen was used as an experimental unit. Where there was a significant F-test $(\mathrm{P}<0.05)$, the least significant difference (LSD) method was used to separate the means (Steel \& Torrie, 1980).

\section{Results}

Table 2 Influence of dietary crude protein (CP) level on feed intake, gain and feed conversion ratio (14-21 weeks growth period)

\begin{tabular}{|c|c|c|c|c|c|c|}
\hline & \multicolumn{6}{|c|}{ Treatments* (g CP/ kg feed) } \\
\hline & 100 & 120 & 140 & 160 & 180 & s.e.d. \\
\hline Feed intake $(\mathrm{g} / \mathrm{b} / \mathrm{d})$ & $47.3^{\mathrm{a}}$ & $57.7^{b}$ & $64.8^{\mathrm{c}}$ & $68.4^{\mathrm{cd}}$ & $70.6^{\mathrm{d}}$ & 2.38 \\
\hline Weight gain $(\mathrm{g} / \mathrm{b} / \mathrm{d})$ & $3.1^{\mathrm{a}}$ & $5.8^{\mathrm{b}}$ & $8.6^{\mathrm{c}}$ & $11.5^{\mathrm{d}}$ & $12.2^{\mathrm{d}}$ & 0.55 \\
\hline $\begin{array}{l}\text { Feed conversion ratio } \\
\text { (feed/gain }),(\mathrm{g} / \mathrm{g})\end{array}$ & $15.6^{\mathrm{a}}$ & $10.1^{\mathrm{b}}$ & $7.6^{\mathrm{c}}$ & $6.0^{\mathrm{d}}$ & $5.8^{\mathrm{d}}$ & 0.61 \\
\hline
\end{tabular}


The influence of the dietary protein level on feed intake, weight gain and feed efficiency is shown in Table 2. Feed intake per bird increased with increasing protein levels of between 100-140 g/ $\mathrm{kg}$, after which the intake plateaued. Furthermore, feed intakes for birds offered diets containing 160 and $180 \mathrm{~g} \mathrm{CP} / \mathrm{kg}$ did not differ $(\mathrm{P}>0.05)$ from each other.

Live weight gain was lower $(\mathrm{P}<0.05)$ for birds offered diets containing 100,120 and $140 \mathrm{~g} \mathrm{CP} / \mathrm{kg}$ in comparison to those offered the diets containing 160 and $180 \mathrm{~g} \mathrm{CP} / \mathrm{kg}$. These weight gains were similar to those obtained for feed intake. Live weight gain increased and feed conversion ratio (FCR) decreased with increasing levels of protein (Table 2). The feed efficiency improved in birds offered diets containing between 100 and $160 \mathrm{~g} \mathrm{CP} / \mathrm{kg}$, but there was no further improvement when the CP level increased from 160 to 180 $\mathrm{g} / \mathrm{kg}$ in the diets.

\section{Discussion}

Growth in animals is influenced by genotype of the birds, and by nutrition, hormones, tissue specific regulatory factors and other aspects of the bird's environment (Carlson, 1969). In a stress-free environment, given adequate intake of essential nutrients, growth will increase until a genetically determined upper limit is reached (Campbell \& Taverner, 1988). Feeding animals below their protein requirement does not improve protein utilization. Protein deficiency in a feed reduces growth as a consequence of depressed appetite and thus intake of nutrients (Harper \& Rogers, 1965). Surplus amino acids in the portal circulation after consumption of an imbalanced diet stimulate synthesis or suppress breakdown of limiting amino acids in the liver leading to their greater retentions. The supply of the limiting amino acids for peripheral tissues such as muscle is thereby reduced, although protein synthesis in these tissues continues unimpeded. Harpers \& Rogers (1965) reported that, in both muscle and plasma the concentration of the first limiting amino acid declines while there is an accumulation of those amino acids, which were added and they precipitated the imbalance. Eventually, the free amino acid patterns of both muscle and plasma may become so deranged that it will trigger the intervention of the appetite-regulating system to reduce feed intake. Growth is depressed as a consequence of the depressed appetite and intake of nutrients. This depression in feed intake may be regarded as responsible for the retardation of growth. Results from this study demonstrate that feed intake increased with increasing protein and amino acids content in the diet (Tables 2 and 3). Both the growth rate and feed conversion ratio of chickens improved as the dietary protein levels increased up to $160 \mathrm{~g} \mathrm{CP} / \mathrm{kg}$. This may be attributed to an increase in available protein and amino acids for growth.

Table 3 Calculated amino acid concentration of the diets (as fed basis)

\begin{tabular}{lcccccc}
\hline & \multicolumn{5}{c}{ Diets (g crude protein/kg) } \\
\cline { 2 - 6 } Amino acid $(\mathrm{g} / \mathrm{kg})$ & 100 & 120 & 140 & 160 & 180 & Requirement* \\
\hline Lysine & 3.5 & 4.7 & 5.8 & 6.9 & 8.0 & 4.5 \\
Methionine & 3.1 & 3.9 & 4.6 & 5.4 & 6.2 & 2.0 \\
Threonine & 3.5 & 4.2 & 5.1 & 6.0 & 6.8 & 3.7 \\
Tryptophane & 0.6 & 0.7 & 0.9 & 1.1 & 1.2 & 1.1 \\
Isoleucine & 5.1 & 5.9 & 7.1 & 8.3 & 9.3 & 4.0 \\
Leucine & 15.0 & 16.0 & 17.4 & 18.8 & 20.1 & 6.7 \\
Valine & 6.7 & 7.5 & 8.5 & 9.5 & 10.5 & 4.1 \\
Phenylalanine & 6.1 & 6.8 & 7.9 & 9.0 & 10.1 & 3.6 \\
Histidine & 3.8 & 4.2 & 4.8 & 5.3 & 5.9 & 1.7 \\
Arginine & 6.0 & 7.3 & 9.2 & 11.0 & 12.7 & 6.7 \\
\hline
\end{tabular}

*NRC (1984)

On the other hand, feeding above the protein requirements does not result in an increase in protein deposition, but nitrogen excretion through the urine increases rapidly (Bikker et al., 1994). In this study growth rate in chickens increased as protein level increased up to $160 \mathrm{~g} / \mathrm{kg}$ and then plateaued, i.e. there was no further increase after this level. The amino acid concentration of typical maize-soya diets (160 and $180 \mathrm{~g}$ $\mathrm{CP} / \mathrm{kg}$ ) meets the requirements of growing layer chickens (NRC, 1984). The feed efficiency improved increasing protein level of the diet. This is in agreement with the findings of Morris et al. (1987) who reported progressive reduction in the efficiency of utilization of lysine as the $\mathrm{CP}$ concentration of the diet increased from 140 to $280 \mathrm{~g} / \mathrm{kg}$. The similar gain and FCR observed for birds offered diets containing 160 
and $180 \mathrm{~g} \mathrm{CP} / \mathrm{kg}$ may be as a result of the $180 \mathrm{~g} \mathrm{CP} / \mathrm{kg}$ diet containing amino acids in excess of the requirement for growing indigenous chickens. This may have led to increased amino acid degradation, resulting in no further increase in growth and efficiency of feed utilization. As the supply of an amino acid is in excess of that required for protein synthesis, amino acid catabolism increases. This ensures that when amino acids are in short supply they are preferentially used for body protein synthesis (Kim et al., 1983). The activity of most amino acid catabolizing enzymes increases with increased dietary supply of protein. Ndegwa et al. (2001) reported that indigenous growing chickens fed diets containing 170-230 g CP/ $\mathrm{kg} \mathrm{had}$ similar growth rates and feed intake, suggesting that the $17 \mathrm{~g} \mathrm{CP} / \mathrm{kg}$ diet was sufficient for these chickens.

In a recent study, Chemjor (1998) reported a FCR of $5.2 \mathrm{~g}$ feed/g gain for indigenous chickens offered diets in a cafeteria feeding system. Between 14 and 21 weeks of age these chickens consumed 10.64 $\mathrm{g}$ protein per day, whereas the chickens on the $16 \mathrm{~g} / \mathrm{kg}$ diet in the present study consumed $10.95 \mathrm{~g} \mathrm{CP}$ and had a FCR of 5.98. Despite the FCR's from both studies being similar, growth rates were lower in the current study (by $5.1 \mathrm{~g} /$ day). This suggests that birds on the free choice feeding system might have been able to finetune their protein intakes. For the complete diets, a higher appetite for protein would lead to an increased intake of other nutrients. This may reduce the efficiency of protein utilization, which will be reflected as poor growth rate and higher FCR.

Since there was no further improvement in rate of growth beyond $160 \mathrm{~g} \mathrm{CP} / \mathrm{kg}$, it suggests that $180 \mathrm{~g}$ $\mathrm{CP} / \mathrm{kg}$ was above the requirement for this group of chickens. The chickens in this study that were fed on the diet containing $140 \mathrm{~g} \mathrm{CP} / \mathrm{kg}$ had a feed intake, growth rate, and FCR of $64.8 \mathrm{~g}, 8.6 \mathrm{~g} / \mathrm{day}$ and 7.6 respectively. Chemjor (1998) reported $81.27 \mathrm{~g}, 16.38 \mathrm{~g} /$ day and 5.13 for feed intake, growth rate and FCR respectively for indigenous chickens consuming a diet containing $140 \mathrm{~g} \mathrm{CP} / \mathrm{kg}$ between the $16^{\text {th }}$ and $21^{\text {st }}$ week. This variation could be due to differences in the methods of determination of the protein requirements. This study used the dose response method while Chemjor (1998) used the cafeteria method.

\section{Conclusions}

The results of this study indicate that, during the 14-21 week growth phase, indigenous chickens require a protein concentration of approximately $160 \mathrm{~g} / \mathrm{kg}$ in their diets to optimise intake and growth rate. These results can be used to calculate protein deficits in scavenging growing chickens if the protein obtained from scavenging is determined. Consequently, this deficit may be offset by offering appropriate supplementation.

\section{Acknowledgements}

This work was funded by the Agricultural Research Fund (ARF) and is appreciated. The authors would like to thank the Centre Director NAHRC, Naivasha for kindly allowing us to use their facilities, the staff in the Poultry Unit, J. Mwangi who assisted in data collection and Mr. Lukibisi for assisting in statistical analysis. We would also like to thank the management of Kenbird Farm for their supply of the ingredients used for the diet formulation.

\section{References}

Bikker, P., Verstegen, M.W.A. \& Tamminga. S, 1994. Partitioning of dietary nitrogen between body components and waste in young pigs. Neth. J. Agric. Sci. 42, 37-45.

Blum, J.C., Guillaum, J. \& Leclercg, B., 1975. Studies of energy and protein requirements of growing guinea fowls. Br. Poult. Sci. 16, 157-168.

Campbell, R.G. \& Taverner, M.R., 1988. Genotype and sex effects on the relationship between energy intake and protein deposition in growing pigs. J. Anim. Sci. 66, 676-686.

Carlson, I.R., 1969. Growth regulators. In: Animal growth and nutrition. Eds. Hafez, E.S.E. \& Dryer, I.A. Publishers: Lea \& Febiger, Philadelphia, USA. pp. 138-155.

Chemjor, W., 1998.Energy and protein requirements of indigenous chickens of Kenya. MSc thesis, Egerton University, Kenya, pp. 83.

FAO, 1997. Human nutrition in the developing world. Latham M.C. FAO Food and Nutrition Series No.29.

Genstat, 1995. Genstat 5, Release 3.2. (Pc/Windows 95,), Lawes Agricultural Trust, Rothamsted Experimental Station.

Gichohi, C.M. \& Maina, J.G., 1992. Poultry production and marketing. Ministry of Livestock Production. Paper presented in Nairobi, Kenya, November 23-27. 
Harper, A.E. \& Rogers, Q.R., 1965. Amino acid imbalance. Proc. Nutr. Soc. 24, 173-190.

Kim, K.I., McMillan, I. \& Bayley, H.S., 1983. Determination of amino acid requirements of pigs using an indicator amino acid. Br. J. Nutr. 50, 369-382.

Morris, T.R., Al-Azzawi, K., Gous, R.M. \& Jackson, G.L., 1987. Effects of protein concentration on responses to dietary lysine by chicks. Br. Poult. Sci. 28, 185-195.

Moughan, P.J., 1989. Simulation of the daily partitioning of lysine in the $50 \mathrm{~kg}$ live weight pig - A factorial approach to estimating amino acid requirements for growth and maintenance. Res. Dev. Agric. 6, 714.

Mukherjee, T.K., 1992. Usefulness of indigenous breeds and imported stock for poultry production in hot climates. In: World's Poult. Congr. September 20-24, 1992. Amsterdam, The Netherlands.

Ndegwa, J.M., Kimani, C.W., Siamba, D., Ngugi, C.N. \& Mburu, B.M., 1996. On farm evaluation of improved management practices on production performance of indigenous chicken. OctoberDecember quarterly report, NAHRC, Naivasha, Kenya.

Ndegwa, J.M., Mead, R., Norrish, P., Kimani, C.W. \& Wachira, A.M., 2001. The performance of indigenous Kenyan chickens fed diets containing different protein levels during rearing. Trop. Anim. Health Prod. 33, 441-448.

NRC, 1984. Nutrient requirements of domestic animals. 1. Nutrient requirements of poultry. National Academy of Sciences, Washington D.C.

Potter, I.M. \& Shelton, J.R., 1979. Methionine and protein requirements of young turkeys. Poult. Sci. 58, 609-615.

Steel, R.D.G. \& Torrie, J.H., 1980. Principles and procedures of statistics. McGraw-Hill Book Company, Inc, New York.

Woodard, A.E., Vohra, P. \& Synder, R.L., 1977. Effects of protein levels in diets on growth of pheasants. Poult. Sci. 56, 1492-1500.

Yamane T., Ono, K. \& Tanaka, T., 1980. Energy requirements of laying Japanese quail. Br. Poult. Sci. 21, 451-455. 